Diabetologia 11, 245-248 (1975)

(c) by Springer-Verlag 1975

\title{
A Scanning Electron Microscopic Study of the Glomerular Epithelial Cells in Alloxan Diabetic Rats
}

\author{
E. Hägg and B. Winblad \\ Departments of Medicine and Pathology, University of Umeå, Umeå, Sweden
}

Received: October 23, 1974, and in revised form: April 2, 1975

\begin{abstract}
Summary. The glomerular epithelial cells in control and alloxan diabetic rats were studied by scanning electron microscopy. The changes observed in the epithelial cells were mainly localized to the terminal foot processes. In one long-term (12 months) diabetic rat a complete fusion of these processes was observed. Rats with long-term alloxan diabetes had generally more advanced glomerular epithelial lesions than age-matched control animals. The glomeruli of
\end{abstract}

rats diabetic for only one month did not appear to differ from those of corresponding controls.

Key words: Alloxan diabetes, rat kidney, glomerular lesions, podocytes, scanning electron microscopy, diabetic microangiopathy, long-term experimental diabetes, semiquantitative assessment.
The scanning electron microscope (SEM) provides an excellent technique for studying the glomerular epithelial cells (podocytes) and their processes (cf. 1, 2,3 ). As no report of a SEM investigation of the changes in the glomeruli of diabetics could be found in the literature, we thought it of interest to supplement an earlier light microscopic, immunofluorescence and transmission electron microscopic study of the glomeruli of alloxan diabetic rats $[7,8,9]$ with a SEM investigation. Special attention is given to the influence of the duration of diabetes on epithelial lesions in the glomeruli.

\section{Material and Methods}

As most of the details of similar experiments have been presented in preceding reports $[7,8,9]$, only a brief outline of the experiment will be presented here. Thirty-five albino rats of both sexes of the highly inbred R-strain raised at the Department of Cell Research, Karolinska Institute, Stockholm, were used in the investigation. The animals were maintained on a conventional laboratory diet and had free access to tap water. Permanent diabetes was induced at the age of 3 months by an intravenous alloxan injection, 55 $\mathrm{mg} / \mathrm{kg}$, during kidney protection [7]. No insulin was given afterwards. Only those animals with permanent polyuria and glucosuria (measured monthly) and a non-fasting morning glucose level of at least $200 \mathrm{mg} /$
$100 \mathrm{ml}$ were used. Blood sugar was measured about 2 weeks and 6 and 12 months after alloxanization and the concentration varied between $204-590 \mathrm{mg} / 100$ $\mathrm{ml}$ (mean $381 \mathrm{mg} / 100 \mathrm{ml}$ ). Control rats were either untreated or given a saline injection during kidney protection at 3 months of age. The non-fasting blood glucose level on the days before sacrifice was always less than $100 \mathrm{mg} / 100 \mathrm{ml}$ in the control animals and none had glucosuria.

Groups of rats were killed at ages 4, 6, 9 and 15 months, corresponding to a diabetes duration of 1,3 , 6 and 12 months. The rats were sacrificed by an overdose of ether. The upper part of the abdominal aorta was ligated and a cannula inserted into the aorta below the renal arteries. An infusion of physiologic saline was connected to the cannula. The pressure of the infusion bottle was adjusted to $120 \mathrm{~mm} \mathrm{Hg}$ and the left kidney perfused with approximately $100 \mathrm{ml}$ of saline. The kidney was then fixed by infusion of $5 \mathrm{ml}$ of a solution of $2.5 \%$ glutaraldehyde in phosphate buffer $(0.1 \mathrm{M}, \mathrm{pH} 7.2)$. The kidney was removed and a longitudinal tissue section, approximately $4 \mathrm{~mm}$ thick, was cut from the cortex and placed in this same fixative for $24 \mathrm{hrs}$ at $4^{\circ} \mathrm{C}$. The section was cut into small cubes $(4 \times 4 \times 4 \mathrm{~mm})$. The specimens were washed in redistilled water, rapidly frozen in isopentan at $-160^{\circ} \mathrm{C}$, and freeze-dried for $18 \mathrm{hrs}$ at $-60^{\circ} \mathrm{C}$ and 0.02 Torr in an Edwards-Pearse Speedivac Tissue Dryer. The specimens were coated with gold to a thickness of about $200-300 \AA$ on a rotating 
stage in a vacuum of $10^{-5}$ Torr in an Edwards Vacuum Coating Unit E4 in which the disc holding the specimens is motor-driven in a combined rotating and tilting movement to ensure even coverage of the specimen's surface. They were examined in a Cambridge Stereoscan S4 scanning electron microscope operating at an tographs taken at the standard magnifications $\times 1000$, $\times 2000, \times 5000$ and $\times 10000$. Details from areas of special interest were photographed at higher magnifications. The classification of epithelial changes was performed without knowledge of the presence of diabetes or age of the rats. Grading of the changes was
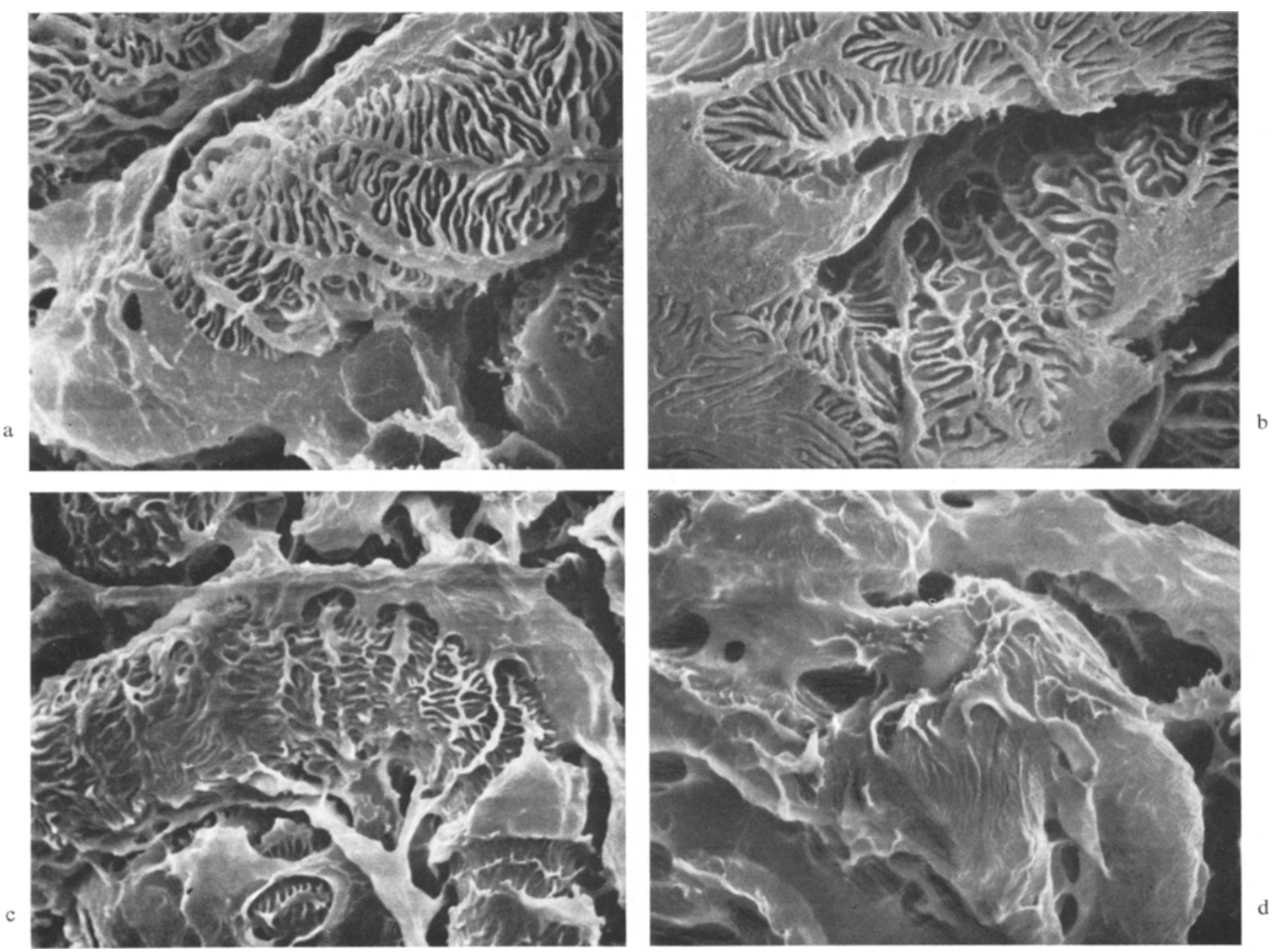

Fig. 1. A series of medium-power scanning electron micrographs of glomerular capillary loops from 15-months old rats. Fig. $1 \mathrm{a}$ is from a nondiabetic control rat and Figs. $1 \mathrm{~b}-\mathrm{d}$ from rats being alloxan-diabetic for 12 months. The series gives the semi-quantitative grading used, viz. Grade 0 (Fig. 1 a): Normal looking foot processes. Grade $1+$ (Fig. 1 b): Somewhat widened and shortened terminal processes. Grade $2+$ (Fig. 1 c): Terminal processes partly fused with indistinct interdigitation. Grade $3+$ (Fig. 1 d): Terminal foot processes not clearly identifiable; a cytoplasmic membrane formed on the capillary loops. $\times 4,000$

accelerating voltage of $10-20 \mathrm{kV}$ and a beam current of $190 \mu \mathrm{A}$. The results were recorded on Agfapan Professional 100 film with a Linhof Super Rollex camera.

From different parts of the tissue sections of each kidney at least three glomeruli which showed no signs of cutting-induced artifacts were investigated. The glomerular epithelial changes were examined on pho- semiquantitative on an arbitrary four point scale $(0$, $1+, 2+$ and $3+$, see Fig. $1 \mathrm{a}-\mathrm{d}$ ):

Grade 0: Normal glomerulus with well-preserved primary, secondary, tertiary and terminal (foot) processes of the podocytes.

Grade $1+$ : Terminal processes somewhat widened and shortened. 
Grade $2+$ : Terminal processes further damaged and partly fused; primary and secondary processes still visible.

Grade $3+$ : Only primary processes clearly visible; a rough cytoplasmic membrane on the capillary loops formed by fusion of terminal processes.

\section{Results}

The differences in the SEM changes in the glomeruli observed between nondiabetic and diabetic rats appeared to be purely quantitative. The lesions of the epithelial cells were mainly localized to the terminal foot processes. In one male rat with long-term diabetes complete fusion of these processes was observed. The lesions of the podocytes often showed both intra- and, particularly, interglomerular variations. lesions of the processes, no distinct differences between the epithelial cells of the glomeruli of diabetic animals and those of the controls could be demonstrated.

\section{Discussion}

As has been demonstrated previously in this laboratory using both light and transmission electron microscopy, alloxan diabetic rats develop lesions resembling those of diffuse glomerulosclerosis seen in human diabetes $[7,8]$. There is evidence indicating that, in diabetics, the epithelial cells of the glomeruli may be involved in the thickening of glomerular basement membrane (cf. 11). Using transmission electron microscopy, changes of the glomerular epithelial cells have been demonstrated both in diabetic humans (cf. 4) and animals (cf. 5), including rats with alloxan dia-

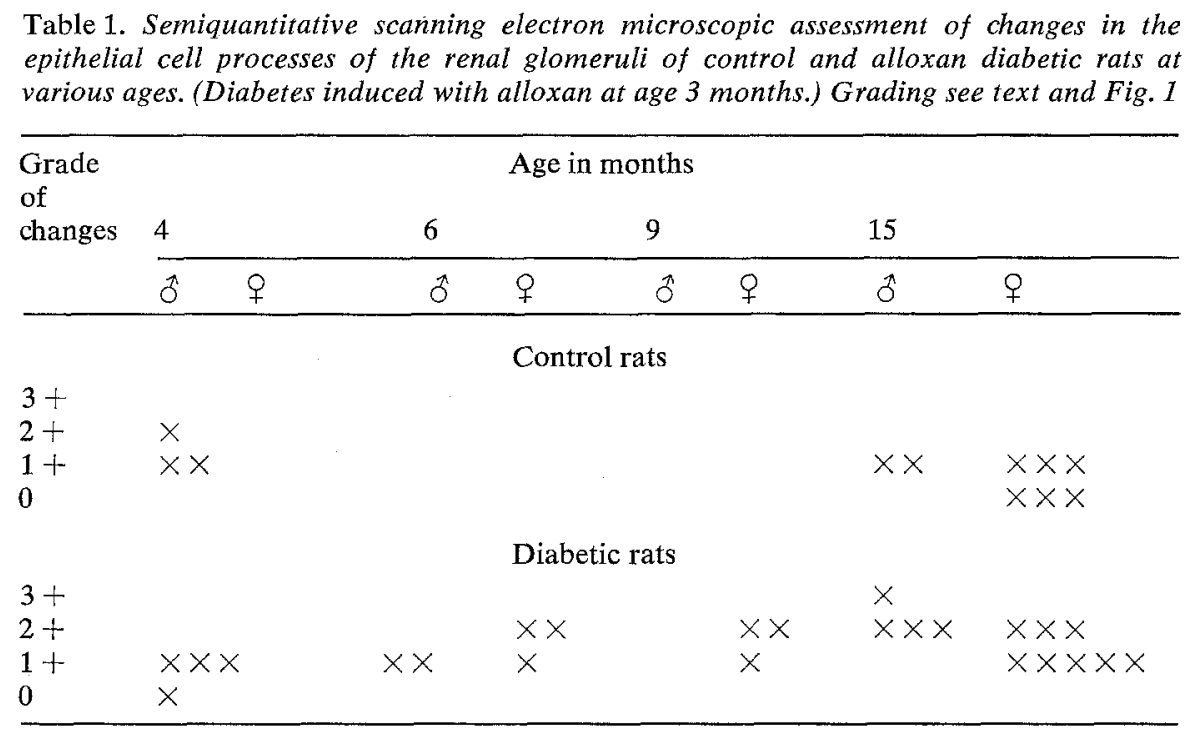

Thus, in the same rat relatively normal glomeruli could be found together with glomeruli with moderately changed podocytes.

The semi-quantitated aspects are summarized in Table 1 . The majority of the diabetic animals aged 15 months had more pronounced SEM changes of the podocytes in the renal glomeruli than nondiabetic controls of corresponding age. The duration of diabetes appears to be of importance as the epithelial cell changes were more marked in 15-month old than in 4-month old diabetic males, whereas an analogous increase in severity did not occur in the nondiabetic controls. However, there was no obvious correlation between the blood glucose level and the severity of epithelial cell lesions in the diabetic animals.

Apart from the quantitative variations in the betes $[6,10,12]$. The lesion most commonly reported is a fusion of the epithelial foot processes.

In the present investigation the predominant lesion seen was a change in the terminal processes progressing from a slight widening and shortening of the processes to a complete coalescence of adjacent foot processes. Slight changes were often observed in nondiabetic rats but the more severe lesions were seen only in the diabetic group. The duration of the diabetes appears to be of importance for the severity of the epithelial changes. These results are in agreement with those of previously mentioned light and transmission electron microscopic studies of glomerular lesions in alloxan diabetic rats of the same strain and treated in the same manner as those used in this study $[7,8]$. 
The pathogenesis of the changes of the glomerular podocytes in diabetes is not known. Furthermore, it is still uncertain as to whether or not the epithelial cells are of importance for the development of diabetic glomerulosclerosis. The results of this investigation indicate that the more advanced lesions of the epithelial cells are secondary to the diabetic state and that they occur concomitantly with basement membrane thickening and widening of the mesangial area in the glomeruli.

Acknowledgements. This work was supported by grants from the Swedish Diabetes Foundation and the Swedish Medical Research Council (Project No. 12X-718).

\section{References}

1. Andrews, P. M., Porter, K. R.: A scanning electron microscopic study of the nephron. Amer. J. Anat. 140, 81-116 (1974)

2. Arakawa, M.: A scanning electron microscopy of the glomerulus of normal and nephrotic rats. Lab. Invest. 23, 489-496 (1970)

3. Buss, H., Lamberts, B.: Das Nierenglomerulum der Ratte bei experimenteller Daunomycinnephrose. Vergleichende durchstrahlungs- und rasterelektronenmikroskopische Untersuchungen. Beitr. Path. 148, 360-387 (1973)

4. Ditscherlein, G.: Nierenveränderungen bei Diabetikern. Jena: VEB Gustav Fischer Verlag 1969

5. Ditscherlein, G.: Zur Frage der Glomerulosklerose bei diabetischen Tieren. Zschr. inn. Med. 25, 281-289 (1970)
6. Ditscherlein, G., Kranz, D., Marx, I., Dena, R.: Elektronenmikroskopische Untersuchungen an Rattennieren bei langdauerndem unbehandeltem Alloxandiabetes. Exp. Path. 4, 222-239 (1970)

7. Hägg, E.: Renal lesions in rats with long-term alloxan diabetes. A semiquantitative light microscopic study with particular reference to the glomeruli. Acta path. microbiol. scand. Sect. A 82, 199--210 (1974)

8. Hägg, E.: Glomerular basement membrane thickening in rats with long-term alloxan diabetes. A quantitative electron microscopic study. Acta path. microbiol. scand. Sect. A 82, 211-219 (1974)

9. Hägg, E.: Occurrence of immunoglobulin and complement in the glomeruli of rats with long-term alloxan diabetes. An immunofluorescence study. Acta path. microbiol. scand. Sect. A 82, 220-227 (1974)

10. Klinger, G.: Histochemische und submikroskopische Untersuchungen an renalen Basalmembranen alloxandiabetischer Ratten und Mäuse. Anat. Anz. 121, 260-271 (1967)

11. Østerby, R.: The number of glomerular cells and substructures in early juvenile diabetes. A quantitative electron microscopic study. Acta path. microbiol. scand. Sect. A 80, 785-800 (1972)

12. Østerby-Hansen, R., Lundbaek, K., Olsen, T. S., Ørskov, $H .:$ Kidney lesions in rats with severe long term alloxan diabetes. III. Glomerular ultrastructure. Lab. Invest. 17, 675-692 (1967)

Dr. E. Hägg

Medicinska kliniken

Lasarettet

S-90185 Umeå 6

Sweden

Responsible for the text: Prof. Dr. W. CReCTzFradr, Med. Universitätsklinik,Humboldtallee 1, D-34 Göttingen/F. R. G. Prof. Dr. K. Schöfeting Gentrum der Inneren Medizin, Theodor-Stern-Kai 7, D-6 Frankfurt 70/F. R. G.

Responsible for advertisements : L. SIEGEL, G. MARTIN, D-1000 Berlin 15, Kurfürstendamm 237. Springer-Verlag, Berlin, Heidelberg, New York Printed in Germany by aprinta, Wemding/Schwaben.

Copyright (C) by Springer-Verlag Berlin - Heidelberg 1975 